INDONESIAN JOURNAL OF

Clinical Pathology and Medical Laboratory

Majalah Patologi Klinik Indonesia dan Laboratorium Medik

\begin{tabular}{|c|c|c|c|c|c|}
\hline $\begin{array}{c}\text { IJCP \& ML } \\
\begin{array}{c}\text { (Maj. Pat. Klin. } \\
\text { Indonesia \& Lab. Med.) }\end{array}\end{array}$ & Vol. 17 & No. 3 & Hal. 127-177 & $\begin{array}{c}\text { Surabaya } \\
\text { Juli 2011 }\end{array}$ & $\begin{array}{c}\text { ISSN } \\
0854-4263\end{array}$ \\
\hline
\end{tabular}

Diterbitkan oleh Perhimpunan Dokter Spesialis Patologi Klinik Indonesia

Published by Indonesian Association of Clinical Pathologists

Terakreditasi No: 43/DIKTI/Kep/2008, Tanggal 8 Juli 2008 


\section{INDONESIAN JOURNAL OF \\ CLINICAL PATHOLOGY AND MEDICAL LABORATORY \\ Majalah Patologi Klinik Indonesia dan Laboratorium Medik}

\section{DAFTAR ISI}

\section{PENELITIAN}

Creatine Kinase Myocardial Band, Myeloperoxidase, Matrix Metalloproteinase- 9 dan Troponin T Pada IMA

(The Creatine Kinase Myocardial Band, Myeloperoxidase, Matrix Metalloproteinase-9 Activities and Troponin $T$ in Myocardial Infarction)

IA Hutagalung, I Patellongi, R Pakasi, M Arif, AA Mappahya, Hardjoeno

D-Dimer Penderita Sindrom Koroner Akut dan Stenosis

(D-Dimer in Acute Coronary Syndrome and Stenosis)

Birhasani, Lisyani BS, Ria T

Uji Hematologi Pasien Terduga Demam Berdarah Dengue Indikasi Rawat Inap

(Hematology Test of Dengue Hemorrhagic Fever on Suspected Patients Indicated for Hospitalization) Juranah, Darwati Muhadi, Mansyur Arif, Burhanuddin Bahar .

Imunokimiawi PGE2 Usus Ileum yang Kekurangan Energi Protein

(Immunohistochemistry of PGE2 Ileum Intestine Protein Energy Deficiency)

R. Heru Prasetyo

Gamma-glutamyltransferase dan Apolipoprotein B dengan Sindroma Metabolik

(Gamma-glutamyltransferase and Apolipoprotein B with the Metabolic Syndrome)

Tahono, M.I. Diah Pramudianti.

146-150

Umbi Ubi Jalar Ungu Bali (Ipomoea batatas) di Transaminase Serum, Malondialdehide Hepar dan Alkohol Kronis

(Balinese Purple Sweet Potato (Ipomoea batatas L) on SGOT, SGPT, MDA level and Chronic Alcohol) I Wayan Putu Sutirta-Yasa, I Made Jawi, Ida Bagus Ngurah, Anak Agung Ngurah Subawa.

Leukosit Infeksi Bakteri Sistemik

(Leucocyte in Systemic Bacterial Infections)

Meita Hendrianingtyas, MI. Tjahjati DM

Meningitis Tuberculosis

(Meningitis Tuberculosis)

Silvia Rachmayati, Ida Parwati, A Rizal, D Oktavia

Platelet Aggregation In Acute Coronary Syndrome

(Aggregasi Trombosit di Sindroma Koroner Akut)

Sulianty, Adi K Aman.

TELAAH PUSTAKA

Pemetaan Epitop dan Aplikasi Klinisnya

(Epitope Mapping and It's Clinical Aplication)

Jusak Nugraha.

LAPORAN KASUS

Infeksi Virus Rabies di Anak-anak

(Rabies Virus Infection in Children)

A.A.N. Subawa, DGD. Dharma Santhi, A.A Raka Sudewi, IWP. Sutirta Yasa 


\title{
UMBI UBI JALAR UNGU BALI (Ipomoea batatas) DI TRANSAMINASE SERUM, MALONDIALDEHIDE HEPAR DAN ALKOHOL KRONIS
}

\author{
(Balinese Purple Sweet Potato (Ipomoea batatas L) on SGOT, SGPT, MDA level and \\ Chronic Alcohol)
}

\author{
I Wayan Putu Sutirta-Yasa, ${ }^{1}$ I Made Jawi, ${ }^{2}$ Ida Bagus Ngurah, ${ }^{2}$ Anak Agung Ngurah Subawa ${ }^{1}$
}

\begin{abstract}
Oxidative stress as a consequence of chronic alcoholic intake causes lesions of liver tissue. The objective of this study was to identify the antioxidant effect of ethanol extract derived from Balinese purple sweet potato on the liver tissue in mice after chronic consumption of alcohol. Subjects of this study were 32 adults male Swiss mice (12-14 weeks) divided into 4 groups with control group post-test only design. Post-treatment of blood and liver samples were collected from each group of 8 mice. The MDA liver was quantified with thiobarbituric acid reactive substances (TBARS) method. Samples were collected from control group of 8 mice without sweet potato extract and alcohol, 8 mice with $1 \mathrm{mg}$ extract of Balinese purple sweet potato, 8 mice with 0.8 gram alcohol, and 8 mice with combine of alcohol and extract of Balinese purple sweet potato, each treatment was carried out every day for 4 weeks. The results showed a significant increase of serum SGOT, SGPT and liver MDA level, after chronic consumption of alcohol $(p=0.00)$. The decrease of serum SGOT, SGPT and liver level MDA was significant in the group with extract of Balinese purple sweet potato $(p=0.00)$. The researchers concluded that the extract of Balinese purple sweet potato had an antioxidant effect in mice which consumed alcohol chronically. Based on this study it is concluded that extract of Balinese purple sweet potato has a protective effect on the liver cell in mice which consumed alcohol chronically.
\end{abstract}

Key words: Chronic alcohol consumption, Balinese purple sweet potato, SGOT, SGPT, liver MDA

\begin{abstract}
ABSTRAK
Oksidatif stres sebagai akibat mengkonsumsi alkohol menahun dapat menimbulkan jejas di hati (hepar). Tujuan penelitian ini adalah untuk mengetahui pengaruh antioksidan dalam ekstrak etanol ubijalar ungu Bali guna menjaga jaringan hati di tikus setelah mengkonsumsi alkohol menahun. Subjek penelitian adalah 32 mencit jantan dewasa (12-14 minggu) galur Swiss, yang dibagi menjadi 4 kelompok dengan rancangan hanya kelompok pembanding pascauji (control group post-test only design). Setelah perlakuan, untuk setiap kelompok sampel (serum dan jaringan hati tikus) diambil dari 8 tikus. Pemeriksaan malondialdehide (MDA) memakai metode thiobarbituric acid reactive substances (TBARS). Sampel dikumpulkan dari 8 tikus kelompok pembanding tanpa diberi ekstrak etanol dan alkohol, 8 tikus diberi 1 mg ekstrak ubi jalar ungu Bali, 8 tikus diberi 0,8 gram alkohol, dan 8 tikus diberi alkohol dan ekstrak ubi jalar ungu Bali, masing-masing perlakuan tersebut dilakukan setiap hari, selama 4 minggu. Hasil penelitian menunjukkan peningkatan kadar SGOT, SGPT yang berarti dari darah dan MDA sel hati, setelah mengkonsumsi alkohol menahun $(\mathrm{p}=0,00)$. Penurunan kadar SGOT, SGPT dalam darah dan MDA hati lebih rendah secara berarti di kelompok dengan pemberian ekstrak ubi jalar ungu Bali, dibandingkan dengan yang tidak diberi ekstrak tersebut $(p=0,00)$. Dari temuan ini dapat disimpulkan bahwa ekstrak ubi jalar ungu Bali mempunyai pengaruh antioksidan di tikus yang diberi alkohol menahun. Ekstrak ubi jalar ungu Bali memiliki pengaruh perlindungan terhadap stres oksidasi di sel hati tikus yang diberi alkohol menahun.
\end{abstract}

Kata kunci: Alkohol menahun, ubi jalar ungu Bali, SGOT, SGPT, malondialdehide

\section{PENDAHULUAN}

Dewasa ini peminum alkohol semakin meningkat, sementara banyak peneliti telah membuktikan bahwa meminum alkohol baik akut maupun menahun dapat menimbulkan kerusakan hati dengan berbagai mekanisme. Mekanisme utama adalah akibat timbul radikal bebas setelah pemberian alkohol. Hasilan Tumor Necrosis Faktor- $\alpha$ (TNF- $\alpha$ ) yang meningkat juga merupakan faktor utama dalam patogenesis kerusakan jaringan hati akibat alkohol. Penyebab kenaikan TNF- $\alpha$ adalah stres oksidatif dan endotoksin. ${ }^{1}$ Di samping dengan mekanisme tersebut, etanol diduga dapat menurunkan kadar antioksidan dan aktivitas glutathione peroxidase. Etanol meningkatkan cytochrom P 450 2E1. 2 Tingkat kerusakan jaringan tubuh akibat radikal bebas dapat diukur dengan mengukur kadar malondialdehide (MDA) di dalam darah dan jaringan yang merupakan penunjuk lipid peroxidation. ${ }^{3}$

Untuk mencegah kerusakan sel akibat kelebihan radikal bebas/stres oksidatif, diperlukan antioksidan. Antioksidan dibedakan menjadi dua kelompok yaitu antioksidan ensimatik dan non ensimatik.

\footnotetext{
${ }^{1}$ Dep. Patologi Klinik, FK. Universitas Udayana/RS. Sanglah. E-mail: psutirtayasa@yahoo.com

2 Dep. Parmakologi, FK. Universitas Udayana/RS. Sanglah
} 
Antioksidan enzimatik disebut juga antioksidan pencegah, yang terdiri dari superoxide dismutase, catalase dan glutathione peroxidase. Antioksidan non enzimatik disebut juga antioksidan pemecah rantai. Antioksidan pemecah rantai terdiri atas vitamin C, vitamin $\mathrm{E}$ dan beta karotin, ${ }^{4-6}$ dan antosianin yang merupakan zat warna alami di tumbuh-tumbuhan. Antosianin merupakan salah satu antioksidan yang mampu mencegah berbagai jenis kerusakan akibat stres oksidatif sehingga dapat melindungi sel dari radikal bebas.

Tumbuh-tumbuhan yang ada di Bali telah banyak diteliti dan ternyata umbi ubi jalar ungu mengandung antioksidan cukup tinggi hampir sama dengan buah bilberi (bilberry). Kandungan antosianin dari umbi ubi jalar ungu adalah berkisar antara $110 \mathrm{mg} / 100$ gram sampai $210 \mathrm{mg} / 100$ gram. ${ }^{7}$ Ubi jalar ungu tersebut telah diteliti dan telah dikembangkan dalam berbagai bentuk suplemen yang siap pakai. Penelitian tentang umbi ubi jalar ungu di mencit telah membuktikan pengaruh antioksidan yang cukup baik. ${ }^{8}$ Penelitian mengenai kemampuan ubi jalar ungu sebagai antioksidan khususnya terhadap hati akibat alkohol menahun belum ada, sementara budi daya tanaman ini tidak sulit untuk dikembangkan. Oleh karena itu penelitian khasiat antioksidan dari umbi ubi jalar ungu terhadap hati perlu dilakukan.

Tujuan penelitian ini adalah untuk mengetahui apakah ekstrak umbi ubi jalar ungu dapat menurunkan kadar malondialdehide hati dan kadar SGOT, SGPT akibat pemberian alkohol di mencit secara menahun.

\section{METODE}

Penelitian ini adalah percobaan (eksperimental) laboratorik dengan rancangan hanya kelompok acak pembanding pascauji (randomized control group post-test only design), mulai bulan Maret 2008 sampai Desember 2008. Tempat penelitian di Bagian Farmakologi FK Unud, Bagian Patologi Klinik FK Unud dan Lab. Gizi UGM Yogyakarta. Sampel dalam penelitian ini adalah mencit jantan galur Swiss dewasa umur 12-14 minggu yang diperoleh dari animal unit Lab. Gizi Universitas Gadjah Mada Yogyakarta. Besar populasi dalam penelitian ini adalah 32 ekor, perumusan didapat dari rumus
Pocock, $\mathrm{N}=\left(2 \delta^{2} /(\mu 2-\mu 1)^{2}\{\mathrm{f}(\alpha, \beta)\}\right.$ yaitu $\delta=15,31$; $\mathrm{u} 2=170,2 ; \mathrm{u} 1=44,6 ; \mathrm{f}(\alpha, \beta)=10,5$ yang diambil dari penelitian terdahulu. ${ }^{8}$ Populasi dibagi menjadi 4 (empat) kelompok masing-masing 8 (delapan) ekor mencit. Kelompok 1 adalah kelompok pembanding yang diberi makanan baku yang disukai (standard ad libitum) selama 4 minggu. Kelompok 2 adalah kelompok yang diberi makanan baku dan ekstrak etanol umbi ubi jalar ungu $1 \mathrm{mg}$ setiap hari selama 4 minggu. Kelompok 3 adalah kelompok yang diberi makanan baku dan alkohol 0,8 gram setiap hari selama 4 minggu. Kelompok 4 adalah kelompok yang diberi makanan baku, alkohol 0,8 gram setiap hari dan ekstrak etanol umbi ubi jalar ungu $1 \mathrm{mg}$ setiap hari selama 4 minggu. Setelah perlakuan selama 4 minggu diperiksa pascauji (post-test) terhadap semua mencit, dengan mengambil darah lewat rongga lekuk mata (sinus orbitalis) untuk pemeriksaan enzim/enzima SGOT dan SGPT. Mencit lalu dilakukan euthanasia dengan eter dan dibedah untuk diambil jaringan hatinya. Pemeriksaan kadar MDA hati dilakukan dengan cara thiobarbituric acid reactive substances (TBARS). Uji statistik yang digunakan adalah ANOVA dan LSD.

\section{HASIL DAN PEMBAHASAN}

Hasil telitian untuk melihat perubahan rerata SGOT, SGPT dan rerata MDA hati di ke empat kelompok binatang percobaan dapat dilihat di Tabel 1. Di Tabel 1 terlihat variabel SGOT, SGPT serum dan MDA hati meningkat bermakna di kelompok yang diberi alkohol selama 4 minggu $(\mathrm{p}=$ 0,00 ). Bila dibandingkan antara kelompok yang diberi alkohol dan ekstrak umbi ubi jalar ungu terlihat kenaikan SGOT dan SGPT jauh di bawah kelompok yang diberi alkohol saja, perbedaan tersebut secara statistik bermakna $(\mathrm{p}=0,00)$. Untuk variabel MDA hati ada perbedaan yang bermakna antara kelompok pembanding dan kelompok yang diberi alkohol menahun $(\mathrm{p}=0,00)$. Pemberian alkohol menahun meningkatkan MDA sangat bermakna $(p=0,00)$. Pemberian ekstrak umbi ubi jalar ungu dapat menurunkan MDA hati di kelompok yang diberi alkohol menahun $(\mathrm{p}=0,00)$. Pada kelompok yang diberi alkohol dan ekstrak umbi ubi jalar ungu bersamaan ternyata kadar MDA hati hampir sama dengan kelompok pembanding $(\mathrm{p}=0,21)$.

Tabel 1. Rerata SGOT, SGPT dan MDA hati 4 kelompok binatang percobaan

\begin{tabular}{lccrc}
\hline \multirow{2}{*}{ Kelompok } & SGOT & SGPT & \multicolumn{1}{c}{ MDA } & \multirow{2}{*}{ Sig. (p) } \\
\cline { 2 - 4 } & Rerata (SD) & Rerata (SD) & Rerata (SD) & $(1)(2) 0,00$ \\
Pembanding (1) & $18,34(2,11)$ & $21,89(0,23)$ & $5,88(0,52)$ & $(2)(3) 0,00$ \\
Alkohol menahun (2) & $33,13(0,27)$ & $40,45(0,35)$ & $13,47(0,63)$ & $(3)(4) 0,21$ \\
Ubi jalar Ungu (3) & $18,78(0,23)$ & $21,17(0,17)$ & $4,94(0,35)$ & $(4)(2) 0,00$ \\
Ubi jalar + Alkohol(4) & $19,46(0,23)$ & $22,52(0,19)$ & $5,58(0,34)$ & $(1)$ \\
\hline
\end{tabular}


Pada penelitian ini pemberian alkohol dengan 0,8 gram perhari selama 4 minggu menyebabkan terjadi kenaikan SGOT, SGPT serum, dan MDA hati secara bermakna dibandingkan dengan kelompok pembanding, baik kelompok ubi jalar maupun kelompok gabungan alkohol dengan ubi jalar. Penelitian ini sesuai dengan penelitian yang telah dilakukan oleh Kanbagli dkk ${ }^{9}$ dengan binatang coba tikus putih/rat yang diberi alkohol 20\% dalam air minum selama 3 bulan (sesuai dengan 8,5 g etanol/ $\mathrm{Kg}$ berat badan perhari) menyebabkan kenaikan yang sangat bermakna dari SGOT dan SGPT dalam serum yang juga terjadi kenaikan kadar MDA hati.

Penelitian yang dilakukan oleh Zhou dkk ${ }^{1}$ di mencit yang diberikan alkohol akut, juga menunjukkan peningkatan SGPT setelah pemberian alkohol 6 gram/kg BB lewat mulut selama 6-12 jam. Pemberian alkohol akut juga menyebabkan peningkatan TNF- $\alpha$ setelah 6-12 jam. Peningkatan MDA hati juga terjadi mulai 1,5 jam setelah pemberian alkohol dan kadar MDA hati tetap tinggi sampai 6-12 jam setelah pemberian alkohol akut. Penelitian yang dilakukan oleh Carmiel-Hagai $\mathrm{dkk}^{2} \mathrm{di}$ tikus gemuk yang diberi alkohol akut, menimbulkan kematian sel dan kerusakan jaringan hati yang lebih berat dibandingkan dengan tikus normal, karena terjadi stres oksidatif, yang ditandai oleh kenaikan SGPT. Penyebab kerusakan jaringan hati di tikus gemuk karena gangguan di antioksidan yaitu terjadi penurunan glutathion, glutamate cysteine ligase, catalase, glutathion reductase dan superoxide dismutase di tikus gemuk. Pemberian alkohol lebih menurunkan kadar antioksidan tersebut dan menurunkan aktivitas glutathione peroxidase. Alkohol meningkatkan cytochrom P 450 2E1.2 Alkohol menyebabkan kerusakan hati dan inflamasi berat tikus, karena terjadi peningkatan chemokines, lipid peroxidase dan endotoksin. Peningkatan lipid peroxidase dan endotoxemia merangsang/mengaktifkan NF-kB dan peningkatan hasilan chemokines. Kerusakan hati akibat alkohol diduga akibat tekanan oksidatif dan endotoksin. Lipid peroksidase yang meningkat akibat peningkatan CYP2E1 yang juga menyebabkan kerusakan jaringan hati. Chemokines juga dapat merangsang pelepasan radikal bebas dari sel Kupffer dan neutrofil, sehingga memperberat stres oksidatif. ${ }^{10}$

Peningkatan kadar SGOT dan SGPT baik setelah pemberian alkohol akut maupun menahun adalah merupakan petanda dari kerusakan jaringan hati. Kerusakan jaringan hati oleh alkohol terjadi karena tekanan oksidatif, yaitu keadaan tidak keseimbangan antioksidan dan radikal bebas di dalam jaringan. Akibat pemberian alkohol kepada hewan atau manusia terbentuk radikal bebas, yaitu dapat melalui beberapa cara: mitochondrial electron transport chain, induksi cytochrom P450 (CYP) 2 E1, dan aktivasi fagosit.
Tekanan oksidatif akan menyebabkan nekrosis/ apoptosis sel hati. ${ }^{11}$ Penelitian yang dilakukan oleh Castilla dkk ${ }^{12}$ membuktikan bahwa terjadi kerusakan sel hati di biakan jaringan hati tikus dan manusia yang diberikan alkohol $10 \mathrm{mmol} / \mathrm{L}$ selama 24 jam, dan berakibat terjadi apoptosis dan nekrosis sel hati. Penelitian yang dilakukan oleh Castilla dkk, membuktikan akibat pemberian alkohol di biakan jaringan hati tikus, menyebabkan peningkatan MDA secara bermakna. ${ }^{12}$ Penelitian yang dilakukan oleh Perez dkk. di penderita sirosis yang biasa meminum alkohol di atas 50 gram perhari selama lebih dari 10 tahun didapat inflamasi di jaringan hati dan peningkatan MDA yang sangat berhubungan dengan kerusakan fungsi hati yang ditandai dengan peningkatan bilirubin secara bermakna. ${ }^{13}$ Kerusakan sel akibat etanol disebabkan interaksi etanol dengan membran yang akan menyebabkan gangguan fungsi membran dalam menyampaikan tanda antarsel. Diduga etanol merangsang terbentuknya asetaldehide serta menurunnya rasio NAD+/NADH. Peningkatan kepekatan Ca menyebabkan kerusakan sitosklet, menurunnya ATP dan meningkatkan keracunan etanol, sehingga bisul kecil (blebs) meningkat. ${ }^{14}$

Pemberian ekstrak etanol umbi ubi jalar ungu dengan dosis $1 \mathrm{mg}$ /ekor/hari yang diberikan bersama alkohol dengan dosis 0,8 gram/hari/ekor lewat mulut selama 4 minggu ternyata dapat menurunkan kadar SGOT, SGPT serum dan juga menurunkan kadar MDA hati secara bermakna $(\mathrm{p}<0,05)$. Dalam penelitian ini terbukti bahwa ekstrak umbi ubi jalar ungu dapat melindungi jaringan hati dan mengurangi stres oksidatif yang disebabkan oleh pemberian alkohol. Antosianin yang terdapat di umbi ubi jalar ungu berfungsi sebagai antioksidan, sehingga kadar MDA hati tidak meningkat. Antosianin adalah flavonoid tertentu yang dapat menetralkan radikal bebas di jaringan hati. Penelitian ini sesuai dengan penelitian di tikus putih/rat yang diberi suntikan etanol 3 gram/ $\mathrm{Kg}$ BB secara di dalam selaput perut/intraperitonial (35\% dalam $\mathrm{NaCl} 0,9 \%$ ) selama 6 minggu menunjukkan peningkatan MDA hati. Pemberian etanol yang diawali dengan pemberian resveratrol (flavonoid tertentu yang didapat di anggur) lewat mulut ternyata dapat menurunkan MDA secara bermakna. ${ }^{15}$ Menurut penelitian Keung (1993, dikutip dari Middleton dkk). ${ }^{16}$ isoflavon flavonoid tertentu dapat menurunkan asupan alkohol di hamster.

\section{Kelemahan Penelitian}

Dengan memakai rancangan randomized control group post-test only design, peneliti berasumsi bahwa homogenitas data pra uji adalah serbasama karena memakai hewan mencit yang dibandingkan dengan prasyarat tertentu. Hasil telitian lebih baik bila rancangan randomized control group post-test only design. Pemberian alkohol 0,8 gram tidak disertai 
dengan pengukuran kadar alkohol dalam serum mencit. Hasil telitian lebih baik bila kadar zat/bahan yang diteliti diketahui kadarnya dalam serum sebelum di uji pengaruhnya.

\section{SIMPULAN DAN SARAN}

Didasari hasil telitian ini dapat disimpulkan bahwa: ekstrak umbi ubi jalar ungu dapat menurunkan kadar malondialdehide di hati mencit akibat pemberian alkohol menahun. Ekstrak umbi ubi jalar ungu dapat menurunkan kadar SGOT dan SGPT akibat pemberian alkohol menahun di mencit. Penelitian perlu dilakukan di hewan yang secara biologis mendekati manusia (seperti kelinci atau kera) sebelum melakukan penelitian tersebut di manusia.

\section{DAFTAR PUSTAKA}

1. Zhou Z, Wang L, Song Z, Lambert JC, McClain CJ, Kang YJ. A Critical Involvement of Oxidative Stress in Acute AlcoholInduced Hepatic TNF- $\alpha$ Production. American Journal of Pathology. 2003; 163: 1137-1146.

2. Carmiel-Haggai M, Cederbaum AI, Nieto N. Binge ethanol exposure increases liver injury in obese rats. Gastroenterology Dec, 2003; 125(6): 1818-33.

3. Clarkson PM, Thomson HS. Antioxidants: What role do they play in physical activity and health? Am J Clin Nutr. 2000; 729 (2 suppl): 637s-46s.

4. Tjokroprawiro A. Radikal Bebas, Aspek Klinik dan Kemungkinan Aplikasi Terapi. Simposium Oksidan dan Antioksidan. Surabaya. 1993.

5. Chevion S, Moran DS, Heled Y, et al. Plasma antioxidant status and cell injury after severe physical exercise, Proc. Nati. Acad. ci. USA, 2003; 100 (issue 9): 5119-5123.
6. Ji LL. Antioxidants and Oxidative Stress in Exercise, Proceeding of the Society for Expeerimental Biology and Medicine. 1999; 222: 283-292.

7. Suprapta DN. Kajian Aspek Pembibitan, Budi daya dan Pemanfaatan umbi-umbian sebagai sumber pangan alternatif. Laporan Hasil Penelitian. (Kerja sama BAPEDA Propinsi Bali dengan Fakultas Pertanian UNUD. 2004).

8. Jawi IM, Suprapta DN, Dwi SU, Wiwiek IA. Efek antioksidan ekstrak umbi ubijalar ungu pada darah dan berbagai organ pada mencit yang diberikan beban aktivitas fisik maksimal, (Bappeda Provinsi Bali 2006).

9. Kanbagli O, Balkan J, Aykac-Toker G, Uysal M. Hepatic Mitochondrial Prooxidant and Antioxidant Status in EthanolInduced Liver Injury in Rats. Biol. Pharm. Bull, 2002; 25(11): 1482-1484.

10. Nanji AA, Jokelainen K, Fotouhinia M, et al. Increase severity of alcohol liver injury in female rats: role of oxidative stress, endotoxin, and chemokines. Am J Physiol Gastrointest Liver Physiol. December, 2001; 281(6): G1348-G1356.

11. Albano E. Alcohol, oxidative stress and free radical damage. Proceeding of the Nutrition Society, 2006; 65: 278-290.

12. Castilla R, Gonzalez R, Fouad D, Fraga E, Muntane J. Dual Effect of Ethanol on Cell Death in Primary Culture of Human and Rat Hepatocytes. Alcohol and Alcoholism, 2004; 39(4): 290-296.

13. Perez MJS, Gonzalez-Reimers E, Santolaria-Fernandez, VegaPrieto MJDL, Martinez-Riera A, Gonzalez PA, Rodriguez ER, Duran-Castellon MC. Lipid Peroxidation and Serum Cytokines in Acute Alcoholic Hepatitis. Alcohol and Alcoholsm 2006; 41(6): 593-597.

14. Nelson Simanungkalit Pospos L-Ornitin-L-Aspartat (LOLA) Menghindari Blebbing akibat Keracunan Etanol pada Hepatosit. Cermin Dunia Kedokteran International Standard Serial Number, 2005; 125-913: 57-59.

15. Kasdallah-Grissa A, Mornagui B, Aouani E, Hammami M, Gharbi N, Kamoun A, El-Fazaa S. Protective Effect of Resveratrol on Ethanol-Induced Lipid Peroxidation in Rats. Alcohol and Alcoholism. 2006; 41(3): 236-23.

16. Middleton E, Kandaswami C, Theoharides CT. The Effect of Plant Flavonoids on Mammalian Cells: Implications for Inflammation, Heart Disease, and Cancer. Pharmacological Reviews. 2000; 52(4): 673-751. 